2 にしたと答えた。しかしながらての実験の場合，基礎 溲度を一定にしいるいるなホ小条件で検索する必要があ ろう。また投与量と I.D を示すならばスキャン条件も 明記する必要があると共に，陽性描画の場合，最低力ウ ントでのI.Dを示すべきであるう。いずれにしてお counts $/ \mathrm{cm}^{2}$ が多ければ多いほどシンチホトは見やすく なるが，患者の年齢，性別，病状等により R.I の投与 量とスキャン条件を变化させる必要がある.151 府はシ ンチグラムを中央管理する大病院からの報告であり，か なり正確なシンチグラムの複写画像を得ていたが，乙の 報告をベースにし病院の規模によりそれぞれの施設で検 馀していくべき事であるう。

\section{RI III（体外計測)}

座長 金尾，啓在（侍:友病院）

\section{R1 検査における污染の問題点について}

大阪市立大学医学部附属病院·中央放射線部

椎崎 信总・光田 秀雄・浜田 国雄

池田 穂積・志田 梨影

RI 検查時における污染の問題について検討しその対 策を考えた。(1)バイアルビンから RI を抜き取る際ビン 栓部及び周辺部を污染するのはビン内が陽压になってい るとと及びビン栓部の椇傷によることが判った。(2)シリ ンジ内の air 抜きの際酒精綿を針先にあてた場合最高で $50 \mu \mathrm{Ci}$ のI が附着していた. 患者に使用出来ず所定の 容器に入れている. (3)患者の静注部位に使用した酒精綿 への污染は最高 $32 \mu \mathrm{Ci}$ の RI が附着していた。検 查結 果に悪影響を及ぼす場合もあり回収して所定の容器に入 れている.(4)静注部位からの血流の漏れ，小览の場合尿 の漏れ等の涯染もあり検出器の下では原則として静注し ない、検榃台にビニール引き口紙を敷く等も必要です。

153. シンチグラム撮像開始時間の検討 (1) 肝蔵につ いて

九州大学医学部附㾖病院 放射線部

田暤 聖正・村村 睦子 中野秀一郎・森定義

朋シンチグラムを撮る場合, 静注後, 何分から撮像開 始すべきかを検討した。静注開始と共に，シンチカメう を通じてコンピュータに取り这ませ, 朋右葉部, 肝左葉 部, 肝葉間部, 心臓部, 脾臟部, 骨髄部, バックグラン ドについて，ダイナミック・カーブを画かせ，集積飽和 值を求めた，又右葉部に刘するそれぞれの比を求め，最 あ適した撮像開始時間を定めた：集積飽和時間は，テク ネ・フチン酸で13分, テクネ・スズコロイドで11分, 金 コロイドで36分を得た。又，疾患により，洼舅があり，
安全側を取って，テクネ・フチン酸で18分後，テクネ・ スズコロイドで16分後，全コロイドでは，50分後に撮像 開始するととが垶ましいと思われる。

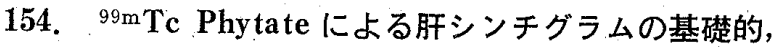
臨床的検討

東京都立大久保病院 放射線科

柴田 准義・船橋 哲哉・作家 計满

山崎 博 - 中川俊夫

東京都立呴边远病院 放射線科

中敷領勝士

99m Tc-phytate は静注後に体内で逝清 Ca とキレート 結合し colloid を形成して網内系の細胞仅込まれる. この ${ }^{99 \mathrm{~m}} \mathrm{Tc}$-phytate における諸種基礎的検討を行ない, 更に肞シンチグラムを施行し，従来行なわれている ${ }^{198} \mathrm{Au}$-colloid による肺ジテグラムと比較検討をした。 [結果]

(1) $99 \mathrm{~m} \mathrm{Tc}$ phytate の調製は極めて簡监であり，常に 高い標識率を示し, 経時的変化す安定である. (2) 尿, 萁便中への ${ }^{99 \mathrm{~m}} \mathrm{TcO}_{4}-の$ 排泄率は，尿中へは投与·量の10\% “前後，翼便中には殆んど認めなかった。(3)動脈血中の半 減時間は1.5〜3.2分の範国にあった。（4)スキャン開始時 閒は, 清注後15分後. (5)肺シンチグラムの脾描出度は, ${ }^{198} \mathrm{Au}$-colloid 乙非常に近似しており, 両者の相関係数 $\gamma=0.99$ であった. (6)浅在性の欠損像に櫌れている. (7) 多方向スキャンが必要.

155. ${ }^{99 m} \mathrm{~T}$ c-Sn-アルブミンの使用経験

埼玉医科大学附属病院 放射線科核医学䛦療部 ○鈴朴 氺行・関 守 雄 長田 篤雄. 中 河広

[目的]

最近各㣫インスタントテタネアルブミンキットが抜 され心プールスキャン等に汎用されているが, 循環血液 量・血漿量・心拍出量の測定などには意外と用いられて いない. そこで現在広く使用されている ${ }^{131}$ I-HSA と比

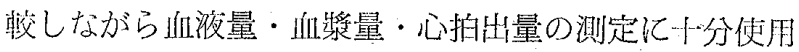
し得るから゙うか検討してみた。

[結果]

13II-HSA と比較し ${ }^{99} \mathrm{Tc}-\mathrm{Sn}$-アルブミンを使用した方 が測定值が高值を示したが， ${ }^{99} \mathrm{Tc}-\mathrm{Sn}$-アルブミの方が相 関がよく, 又三方活栓の吸収約 $3 \%$, 注入場所静脈内の 残存放射能約 $3 \sim 5 \%$ 計 $6 \sim 8 \%$ 補正を行なえば十分に 使用でき得る結果が得られた。

156. RI-Cisternography 用 ${ }^{111}$ In-DTPA について 静岡学災病院

○松村 恕範・堀扑，広志 